\title{
CRITICAL SUCCESS FACTORS TO TAX ADMINISTRATION EFFICIENCY IN NIGERIA: EVIDENCE FROM BAUCHI STATE BOARD OF INTERNAL REVENUE
}

\author{
SHAMSUDEEN LADAN SHAGARIA \\ Faculty of Social Management Science \\ Bauchi State University Gadau, Nigeria \\ NATRAH SAAD \\ Tunku Puteri Intan Safinaz School of Accountancy \\ Universiti Utara Malaysia
}

\begin{abstract}
This study investigates the determinants of tax administration efficiency in Nigeria. The Nigerian tax system is faced with challenges, such as loss of revenue through high level of tax defaulters from both the legislative arm of the government and public institutions, corruption and financial irregularities and limited government administrative capability. Therefore, current study examines the influence of autonomy of the State Board of Internal Revenue (SBIR), use of information and communications technology, public enlightenment, strong auditing practice, motivation and incentives and perceived corruption on tax administration efficiency in Nigeria. A total of 124 questionnaires were collected out of 144 questionnaires that were administered. The study revealed that there is a significant positive relationship between tax administration efficiency and: autonomy of board of internal revenue, information and communications technology and public enlightenment. However, findings from the study revealed that there is insignificant relationship between tax administration efficiency and strong audit practice and motivation and incentives and perceived corruption. Based on the findings above, the study recommended that government should put an effective measure in place to collect taxes from tax defaulters across the different groups of the economy.
\end{abstract}

Keywords: Tax administration efficiency, Autonomy, Strong audit practice, Perceived corruption.

\section{Introduction}

Due to the economic and financial crises, governments at international and national levels have recognized the key role of an efficient tax system in enhancing development, good governance, and adequate revenue generation. According to Ogbonna, (2011), the tax system is an opportunity for the government to raise additional revenue apart from other sources of income, required to carry out its obligations. He further maintained that a sound tax system also offers one of the most effective means of generating a nation's internal resources as well as in creating an enabling environment to promote economic growth and development. Okauru (2011) stated that it is wrong to assume that only the tax authority constitutes a tax system; it encompasses individual taxpayers, institutions (both public and 
private), agencies, the process involved in tax legislation, collection and distribution of tax revenues and other auxiliary issues related to efficient performance of tax functions and the tax system.

However, the Nigerian tax administration is faced with challenges which make it inefficient, as a result of high level of tax defaulters in the country. For example, statistics indicate that tax contributes seven percent to Gross Domestic Product (GDP), which is below the threshold of 15\% for low-income African countries, compared to $22.5 \%$ and over $29 \%$ for medium income and high-income countries, respectively (Okonjo-Iweala, 2013). However, most current statistic indicates a further decrease of one percent, making Nigeria's tax compliance rate at $6 \%$ compared to $16 \%, 15.9 \%$ and $27 \%$ of India, Ghana and South Africa respectively. While most developed nations have tax to GDP ratios of $32 \%$ to $35 \%$ (Adeosun, 2017). The Nigerian minister of finance, further lamented that a six percent tax contribution to GDP is not enough for strong economic development in Nigeria. Similarly, the FIRS (2009) revealed that the Nigerian National Petroleum Corporation (NNPC), Nigerian Universities Commission (NUC) other Ministries, Departments and Agencies (MDAs), as well as the National Assembly have not remitted a total of N72 billion for PITA, VAT and Withholding Tax. Ngama, (2013) reported that about 350,000 incorporated companies in Nigeria had not filed their tax returns in recent years, and about N85.2 billion was lost through tax evasion in the automobile industry alone in the last four years. More recently, FIRS (2017) estimated that they are only 14 million taxpayers in Nigeria, out of which about 96\% have their taxes deducted from source from their salaries. However, this amount of taxpayers indicated a wide variance with the structure of the Nigerian economy, where it was estimated that about 70 million Nigerians are economically active. But only $20 \%$ are duly registered and pays tax (Osibanjo, 2017).

Nonetheless, various scholars have conducted research studies on tax compliance behavior in Nigeria (James, Ariffin \& Idris, 2012; Ojochogwu, \& Stephen, 2012; Fagbemi, Uadile \& Noah, 2010; Sanni, 2006; and Asada, 2005). Other studies focused on the Tax System in Nigeria; for example, Leitman, Okaro, Porter, and Werner (1996) identified a number of factors responsible for the challenges affecting the tax system in Nigeria: inefficient tax administration and collection system, apathy of the Nigerians caused by lack of value received in return for their tax money. The current tax rate under the company income tax act (CITA) is 30\% for incorporated companies operating in Nigeria. A provision of $20 \%$ tax rate is available for small companies engaged in manufacturing or exportation in the first five years of their operations. Petroleum profit tax (PPT) is $85 \%$ and $50 \%$ for joint ventures and production sharing contract. While the personal income tax rate in Nigeria averaged at 24\% from 2011 (David-West, 2013). Examining the burning issues of the Nigerian tax system with analytical emphasis on petroleum profit tax, Ogbonna (2011) highlighted that fraudulent practices and greed, lack of adequate infrastructure, lack of awareness, inefficient tax administration and improper tax planning, monitoring and controlling, as among other key factors affecting the system. Micah, Ebere, and Asian (2012) identified non- 
availability of statistics, inability to prioritize tax effort, poor tax administration and multiplicity of tax, regulatory challenges and corruption as well as the complexity of the laws as the major factors affecting the tax administration efficiency in Nigeria. Similarly, Sanni (2012) studied multiplicity of taxes in Nigeria and observed that corruption, fraud, extortion, lack of data and overlapping taxes are the elements affecting the efficiency of the system.

However, in a study on the challenges and ways to improve the tax system in Nigeria, Micah et al. (2012) highlighted autonomy, use of ICT, strong audit practice, use of tax money and public awareness could enhance tax administration efficiency. Similarly, Abiola and Asiweh (2012) examine the impact of ICT on tax administration efficiency. In view of the foregoing literature, it can be observed that there are some similarities of some factors that affect the Nigerian tax administration as highlighted by different literature which are directly related to taxpayers or tax agent and some factors relate to both parties. Furthermore, most available literature conducted in the area are mostly conceptual, and therefore, an empirical study is needed. Therefore, current research examines the impact of autonomy of the State Board of Internal Revenue (SBIR), use of ICT, public enlightenment, motivation and incentives, strong audit practice and perceived corruption on the tax administration efficiency in Bauchi State. The findings are expected to provide insight on the nature of the problems as well as offer recommendations, by using empirical analysis.

The paper is structured as follows: the next section discusses the previous studies on tax administration efficiency. Then followed by discussions on the key success factors identified as well as developing the research hypothesis. The paper presents the conceptual framework developed for the study. Subsequently, the paper discusses the research methodology used to examine the model. The results of the study are then presented. Finally, discussion on the findings, the limitations of the study, and conclusions was presented.

\section{Literature Review and Hypotheses}

\section{Overview of Tax Administration Efficiency}

An efficient tax administration is a key determinant of investment climate; it helps to attract more investment, reduce poverty and increase growth. It also enables the government to raise revenue with lower tax rates (Rahman, 2009). Erard (1994) stated that the primary goal of a revenue authority is to collect tax due in accordance with laws and in a manner which instills confidence to the taxpayers in the tax system and its administration. A good tax administration is a requisite for ensuring high compliance and administering tax policies effectively and efficiently. Tax Administration in Nigeria involves tax assessment, collection, and accounting of all types of taxes, as well as the implementation of relevant tax laws and governmental policies in Nigeria. It consists of all the strategies and principles adopted by the government to plan, impose, collect, and account for taxes, as well as to coordinate and monitor staff 
who are charged with the responsibility for taxation (Akintoye \& Tashie, 2013). According to Abiola and Asiweh (2012), tax administration in Nigeria refers to those organs and agencies of government that are vested with the responsibility for policy implementation in the country. Tax administration is concerned with duty and responsibility of different tax authorities as enacted by relevant tax laws (Kiabel \& Nwokah, 2009).

However, Nigerian tax system still suffers from high tax defaulters from both individuals and corporate organizations. Therefore, leading to insufficient revenue generation to enable government improves the standard of leaving of it citizens. This has negatively affected the social-economic and infrastructural development and further resulted in the abandonment or delays in completion of many projects that are designed to stimulate the economy and improve the well-being of over 178 million citizens in the country (World Bank, 2015). Some challenges were reported to have hindered tax administration efficiency. Some of the factors impending tax administration includes; inability to prioritize efforts by some tax agencies, poor administration efficiency, failure to file tax return, misreporting of income or allowable deductions from taxable income (Serkan, Tamer, Yuzba \& Mohdali, 2016; Stephen, Ayodotun, Iyoha, Charles \& Deniel, 2017). Also, Sanni (2012) observed that the Nigerian tax system is not in a good state by any measure, policy, law, administration or revenue generation. Sanni further argued that the system is overloaded with many taxes, most of which are overlapping, hence resulting in poor or inefficient tax administration in the country.

Moreover, Nzotta (2007) claimed that tax administration inefficiency might occur when there is highlevel corruption by government officials and lack of fiscal transparency. Nzotta further stated that absence of strong deterrent punishment to prosecute offenders, and lack of awareness or ignorance of tax laws (Asada, 2005). The inefficiency of tax administration might persist when there is a relatively high degree of corruption within the system (Anyanwu, 1993). Similarly, the Chartered Institute of Taxation of Nigeria (CITN, 2002) contended that the government in Nigeria is perceived as corrupt and self-centered, and taxpayers are skeptical of paying their taxes because the tax revenue is not used for the provision of public utilities but rather for lining individual pockets. This causes loss of trust and confidence in the tax system by the taxpayers. Also, administrators are faced with crucial problems related to tax collection because a large segment of the economy is at subsistence level; no records are kept, and even where such records are kept, improper accounts are a predominant characteristic. Furthermore, there is low taxpayer cooperation for various reasons, such as lack of trained officials, corruption and levies do not seem to produce better government services (Ogbonna, 2011). Joon and Kim (2011), in discussing tax administration reforms in Korea, stated that internal tax audits and effective and strong supervision of tax officials are two of the main factors that can enhance revenue generation, as well as the administration efficiency. They further stated that tax revenue could be improved by establishing an effective tax administration, rather than tax policies and laws. However, 
Garde (2004) stated that efficient tax administration requires reform of tax policy and administration, modern and efficient tax processes as well as competent staff.

The Organization for Economic Co-operation and Development (OECD) (2001) posits that an effective tax administration should be concerned with the relationship of employees, taxpayers, the regulatory framework, and environment as well as global changes. Given the tendencies for changes in the global market environment, income tax base is continuously thinning as the government's ability to tax capital flow deteriorates (Gcabo \& Robinson, 2007). However, Olaofe (2008) noted that the starting point of tax administration efficiency in Nigeria is the control of tax evasion. This because the attitude of taxpayers towards complying with the relevant tax laws and procedures can be determined through the extent of tax evasion in the country. Statistical evidence revealed that only $9.9 \%$ of the informal sector paid taxes on their income (Asada, 2005). Alm and Duncan (2013) empirically found that the average performance of OECD countries in collecting taxes is high, but low if compared to non- OECD countries. More recently, Nigeria is categorized among developing countries with the lowest tax compliance. The report further indicated that only about 30\% of corporate firms are tax compliant (African Development Bank Group, 2015). In support of this argument, Ramot and Ichihashi (2012) stated that developing countries tax revenue is largely derived from corporate income tax than personal income tax which is the opposite of the developed nations. This situation has been attributed to the way a particular nation stresses on income redistribution (Gordon \& Li, 2009). Hence, it is imperative that the tax system and tax policies be designed appropriately and monitored continuously for revenue authorities to optimize revenue collection. According to the OECD (2011), tax administration efficiency reduces costs while providing better services to citizens and businesses. The OECD further asserts that efficiency depends on how organizations design their internal organizational structures, how well they allocate their budgeted funds to meet their needs, how they utilize ICT to save costs and how they determine the levels and remuneration of their employees. Similarly, Stephen (2015) stressed the need to have a carefully designed and implemented system for tax incentives in order to influence the efficiency of resources utilization. Lubua (2014) emphases that tax administrator must give much attention to issues such as public enlightenment, training of tax officers, and integrity of the tax administrator, etc. In this regards, the government would be provided with stable resources for the provision of public goods and services that has a direct impact on the lives of the citizens.

\section{Autonomy of Board of Internal Revenue and Tax Administration Efficiency}

Autonomy refers to the degree of independence granted to SBIR in terms of human resources, revenue generation and disbursement and decision-making process which facilitate tax administration. Abiola and Asiweh (2012) defined autonomy as the extent to which government departments or agencies can operate independently in terms of the law and status, human resources, administrative practices, and budgeting. According to Rahman (2009), autonomy increases transparency of the tax administration and 
the effectiveness and efficiency of its expenses. It also minimizes the chances of the administration to be involved in corruption. Crandall (2010) posited that autonomy of government collection agencies could lead to better performance by eliminating problems towards effective and efficient tax administration while maintaining appropriate transparency and accountability. Cekmecelio and Gunse (2011) found that autonomy has a positive relationship with both administrative efficiency and creativity. Administration autonomy increases the quality of services, reduces bureaucracy in implementing management actions as well as improves management efficiency (Evelyn \& Luzira, 2004). Manasan (2003) posited that successful and sustainable revenue authorities are those that have a higher level of autonomy.

London (2013) analyzed the impact of autonomy in a district administration; the result of the study showed that there is a positive relationship between autonomy and the efficiency of the administration, which ultimately increases utilization of human resources, generation of revenue for capital investment in infrastructure and also facilitates decision-making. He further stated that autonomy leads to both technical competency and users' satisfaction. Similarly, Gammelgaard, Mcdonald, Stephan, Selmann, and Christopher (2012) examined the factors that can increase organizational performance and found that autonomy facilitates administration of inter-organizational relationship, which eventually influences efficiency of the organization. However, they further stated that the intention to increase the performance effects of inter-organizational relationship by increasing autonomy needs to be weighed against the possibility of damaging the intra-organizational relationship.

Similarly, Mikesell (2003) argued that autonomy of tax administration make it easier for taxpayers to know what taxes the government has levied upon them, increases transparency and accountability as well as management efficiency. However, Kawai and Strange's (2013) empirical analysis based on cross-sectional data from 88 European subsidiaries of Japanese, argued that autonomy will only have positive impact on performance under conditions of technological uncertainty. Similarly, Onyeukwu (2010) argued that the autonomy of tax administration has brought about the multiplicity of tax burden to the taxpayer. He further added that companies are subjected to different taxes or tax of the same nature by Federal, State or Local Government. Based on the above-mixed findings on autonomy and tax administration efficiency, this variable is measured with four items which were adapted from (Abiola \& Asiweh, 2012; EU, 2007; Verscheure, 2007). Thus, it is hypothesized in an alternative form that:

H1: There is a significant positive relationship between autonomy of the board of internal revenue and tax administration efficiency.

\section{Information and Communications Technology and Tax Administration Efficiency}

ICT is an integrated system which consists of the technology and infrastructure needed to process, store, transmit and deliver information to the end user(s) efficiently. It is an important tool that supports the 
work of government institutions with the objectives of providing public services and information in a convenient, fast and cost-effective manner (Upadhyaya, 2011). In this study, ICT defined as the use of latest information technology to collect, process, disseminate, and or store information (output) to the users for effective decision-making of the SBIR, which in turn lead to tax administration efficiency. James (2013) examined the effect of ICT on secretaries in contemporary organizations. The result revealed that the use of ICT increases innovation, productivity, efficient practices and improves the overall performance of the public sector. In a related study, Edmead et al. (2013) found the use of computers and other electronic gadgets enhances service delivery and increases administration efficiency of the government business. Furthermore, they added that customers believe that the modern system can restore confidence and trust as well as transparency. Acknowledging the infancy level of ICT adoption and implementation in Nigerian tax administration, Stiphen (2015) stated that successful implementation of ICT would enhance the administration processes of tax system and restore public confidence in Nigeria. Abiola and Asiweh (2012) posited that efficient tax administration requires highly trained personnel to align with the sophisticated modern ICT tools. Idisemi and Ann (2011) investigated the impact of ICT implementation in companies. The study employed a case study research method based on two companies and used content analysis. It was found that ICT facilitates effective and efficient communication between the organization and its customers regardless of time and distance; enables the organization to manage data relating to the firm and its customer efficiently, reduces costs and saves time, and enables the firm to produce accurate financial information for decision-making with the use of integrated accounting software. They added that use of computers facilitates timely financial statement; hence audit reports are completed on time.

In a related study, Machupa, Otaigo, Koloseni, and Shimba, (2011) examined the factors influencing decisions on information technology (IT) investment in the public sector and found that the use of the computer system supports the management function of planning, controlling and decision-making. The study further revealed that computers facilitate service delivery, customer satisfaction, information accessibility, efficiency and effective administrative gain as well as information sharing among various units of the government. Decman, Stare, and Klun (2010) examined whether the use of computers improves cost-effectiveness of the government administrative procedures in Slovenia. The result indicated that ICT expenditure is higher than the cost saving for both the taxpayers and tax administration. Similarly, Adeosun (2010) explored the use of ICT in public administration, using qualitative analysis and descriptive research design. It was found that Nigeria is yet to adopt ICT fully, but there is a continuous link between higher efficiency, productivity, and innovation. Based on the above literature on the use of ICT and tax administration efficiency, this variable is measured with four items which were all adapted from Upadhyaya (2011). Hence, it is hypothesized in an alternative form that:

H2: There is a significant positive relationship between ICT and tax administration efficiency. 


\section{Strong Audit Practice and Tax Administration Efficiency}

Tax audit is viewed in this study as the careful assessment of taxpayer account by the SBIR in order to ensure accurate tax are deducted from his/her taxable income. In line with the above definition, Badara, (2012) defined tax audit as an independent examination of tax report of an individual or organization by the relevant tax authority. He further stated strong audit practices would help the government to collect the appropriate revenue and ensure satisfactory returns are submitted by the taxpayers. Similarly, Djawadi and Fahr (2013) studied the impact of tax knowledge and budget spending influence on tax compliance using laboratory research design. It was found that strong audit practice in tax system with high level of authority increases compliance. Similarly, Anyaduba and Modugu (2013) examined the impact of tax audit and qualitative attributes on tax compliance in Nigeria. The result revealed that there is a significant positive relationship between tax audit and tax compliance. The result also indicated that the probability of being audited increases the compliance behavior of the taxpayers. In a related study, Badara (2012) assessed the effect of a tax audit on compliance in Bauchi. The result of the study showed that tax audit enhances revenue generation, reduces tax avoidance and tax evasion.

Palil and Ibrahim (2011) studied the determinants of tax compliance in Malaysia. The result revealed a highly positive correlation between tax audit and tax administration efficiency. Also, Kleven, Knudsen, Kreiner, Pedersen, and Saez (2010) randomly analyzed tax enforcement experiment in Denmark. A stratified sample of more than 40,000 taxpayers was selected. Half of the selected sample was to be intensively audited and the remaining half intentionally ignored. It was found that there is a substantial increase in self-reported income before audits, as a result of past audit experience and the probability of audit detection.

To examine how individuals respond in their compliance decisions to audit certainty and audit productivity, using the experimental method to measure individual response, Alm and Mckee (2006) found that prior notice of taxpayers' auditing increases effective compliance. However, compliance rate of those who know that they will not be audited decline, which overall has a negative effect on the compliance rate. Dubin (2006) investigated whether measurable activities of IRS criminal investigation division affect tax compliance from 1987 to 2004. The result of the analysis revealed that IRS audit activities have a measurable and significant effect on voluntary compliance of taxpayers. Based on the above literature on strong audit practices and tax administration efficiency, this variable is measured with four items adapted from Badara (2012). Therefore, it is hypothesized in an alternative form that:

\section{H3: There is a significant positive relationship between audit practices and tax}

administration efficiency. 


\section{Public Enlightenment and Tax Administration Efficiency}

Public Enlightenment refers to the process of educating and sensitizing the citizens regarding tax matters, i.e., the process of educating and enlightening the general public to carry out their civic responsibility of paying tax as and when due (Badara, 2012). In the context of this study, public enlightenment is defined as the campaign programmes carry-out by the SBIR in order to sensitize the general public on the need to discharge their civic obligation of remitting tax as at when due, to enable to government delivers their primary responsibilities to its citizens. This is in line with the objective of the Nigerian tax system to promote fiscal responsibility and proper accountability. Discussing efficient tax administration towards regional and national development, Williams (2013) identified increased public awareness as a critical factor that can encourage taxpayers to comply with tax legislation. Olowookere and Fasina (2013) studied the impact of tax education program on tax payment compliance attitude. The result showed that the availability of education programs for tax revenue accountability has a significant influence on tax evasion penalty and complexity of tax system as proxies for compliance behavior of taxpayers. Similarly, Djawadi and Fahr (2013) studied the impact of tax knowledge and budget spending influence on tax compliance using laboratory research design. Their results showed that tax knowledge increases compliance in tax systems with low authority.

According to Abiola and Asiweh (2012), enlightenment enables citizens to understand that payment of tax is a civic responsibility and not just a matter of giving and take. This will increase compliance with tax payment and eventually boost government revenue generation. Similarly, Nwanna and Richards (2010) studied the importance of basic tax education among US citizens. They found that enlightened citizenry is comparatively less averse to taxes, less rebellious to government policies with regards to tax matters, less hostile to the IRS and more compliant. These eventually lead to increased government revenue and efficient tax administration. Enlightened taxpayers reduce firms' misconceptions about tax policies and procedures, and educate them on the importance of keeping proper records (Rahman, 2009).

Randlane (2012) examined the compliance behavior of individuals; the study found that tax knowledge plays an important role in developing the behavior of taxpayers. Palil and Ibrahim (2011) studied the determinants of tax compliance in Malaysia. It was found that there is significant relationship between tax knowledge and tax administration efficiency. In a related study, James (2006) examined tax administration efficiency and performance indicators in Thailand and found that awareness and attitudes of tax officials have a positive relationship with revenue collection and productivity of the administration, in both regional and central offices of Thailand. Similarly, Barone and Mocetti (2009) examined the tax morale and public spending inefficiency and found that there is a significantly strong relationship between tax education and compliance behavior of taxpayers. As observed by Chan, Trouhman, and Obryan (2000), tax awareness is directly linked to compliance; they further stated that better understanding of the tax system increases the taxpayers' morale and attitude, leading to increased 
revenue generation. Based on the above discussion on public enlightenment and tax administration efficiency, this construct is measured with four items which were adapted from Badara (2012) and Bose (2014). Thus, it is hypothesized in an alternative form that:

H4: There is a significant positive relationship between public enlightenment and tax administration efficiency.

\section{Motivation and Incentives and Tax Administration Efficiency}

According to Antomioni (1999), motivation is the amount of effort put in the place of work by employees that depends on the levels to which they feel their motivational needs would be satisfied by their employer. However, Robbins and Judge (2008) asserted that motivation refers to the process which accounts for the intensity of an individual, direction and persistent effort towards achieving organizational goals. Based on the context of this study, motivation and incentives refer to the set of mechanism adopted by SBIR in terms of moral support and good salary package to boost their employee's performance which leads to tax administration efficiency. Similarly, Rainey and Steinbauer (1999) studied the theory of effective government organization. The authors asserted that the effectiveness and efficiency of public organizations and or agencies might be improved by inter-relating three components of intrinsic reward, mission, and public services. If public employees perceive their job as important to achieving organizational or agency goals and objectives that can benefit the entire society, then they would put extra effort to ensure their job level goals have been achieved (Wright, 2004).

As observed by the Association of Colleges (2008), incentives and personnel improvement, pay modernization and use of ICT are some of the ways through which administrative efficiency can be measured and improved. Afful-Broni (2012) examined the relationship between motivation and job performance in the University of Mines and Technology. Descriptive survey design was employed with a sample of 200 respondents. The result of the study showed that lack motivation and low monthly package are the main factors that reduce morale and high performance. In a related study, Croxton and Moniz (2009) analyzed employees' motivation within the public sector; they posited that it is very crucial to understand what motivates employees to be productive within their workforce. Furthermore, the overall finding of their studies suggested that employees in public sectors are highly influenced by intrinsic rewards, such as salary. Mougbo (2013) examined the impact of employee motivation on organizational performance in manufacturing companies. Descriptive research design was employed as the methodology of the study and data was analyzed using descriptive statistics. The result of the study showed that extrinsic motivation given to employees in organizations increases efficiency and productivity. 
Solomon, Hashim, Mehdi, and Ajagbe (2012) investigated the effectiveness of motivation and organizational performance in Nigeria. The result showed that adequate motivation improves employee productivity. The authors suggested that organizations should adopt continuous improvement as it can enhance employee efficiency and productivity. Manzoor (2012) examined the correlation between employee motivation and organizational effectiveness. It was found that motivated employees work in the best interests of the organizations which result in higher growth, prosperity and productivity of the firm. Dobre (2013) analyzed the motivational factors that influence employees towards high levels of performance in the organization. Drivers, such as empowerment and recognition of employees, have been found to increase performance towards achieving organizational goals. The author further stated that participation and empowerment of employees do not only improve efficiency, growth, and innovation, but also enhance trust and motivation in the organization. Marsden and Richardson (1992) studied the impact of motivation and performance among Inland Revenue staff. The result of the study showed that staff motivation increases the efficiency and effectiveness of their work.

A motivated and qualified workforce is vital for enhancing service delivery and increasing productivity in an organization. Based on the above literature on staff motivation and incentives, it is clear that very few studies have discussed the public sector, and only the study by Marsden and Richardson (1992), specifically discussed the Inland Revenue staff. The successful application of motivation in the private sector can also be used in the public sector to increase the efficiency of the administrative processes. Hence, current examines the influence of motivation and incentives on tax administration efficiency. This variable is measured with two items adapted from Wright (2004). Thus, it is hypothesized in an alternative form that:

H5: There is a significant positive relationship between motivation and incentives and tax administration efficiency.

\section{Perceived Corruption and Tax Administration Efficiency}

Corruption is defined in the context of this study as sharp practice or dishonest conduct committed by taxpayers through conniving with tax officials to pay less tax. Corruption is a sort of criminal offense which is against the interest of the general public. It violates the moral and legal norms and undermines the rule of law. It is an act of illegal exchange between taxpayer and tax agent or between tax agents, committed for personal gain (OECD, 2012). Simply, corruption can be defined as the abuse of public authority for the purpose of gaining own advantages. Alon and Hagemu (2013) examined the impact of corruption on a firm's tax compliance; the result showed that corruption in transitional economies is highly correlated with influence of peer groups. Similarly, Karimi, Jafari, and Rezaei (2010) investigated the impact of corruption on tax revenue in developing economies; the results indicated that there is a statistically significant relationship between corruption perception index and revenue. Ogbonna (2011) studied the burning issues in the Nigerian tax system. The survey result indicated that greediness and 
corruption are responsible for tax administration inefficiency in Nigeria. In a related study, Cantens, Raballand, and Bilangna (2010) studied the reformation of the public sector (customs services) in Cameroon; the result showed that implementation of new policies by the government reduces corruption and increases administrative efficiency.

Examining the influence of corruption and shadow economy in a cross-section of 98 countries between the periods of 1999 to 2002, Dreher and Schneider (2010) found that there is no strong relationship between corruption and shadow economy when perception based-indices are used. But employing an index structural model base, corruption and shadow economy are found to complement each other in countries with low income only. Similarly, Brasoveanu and Brasoveanu (2009) analyzed the evolution and the relationship between corruption and tax burden among 27 European Union (EU) countries for the periods 1995 to 2008; the econometric results of their study showed that there is negative relationship between corruption and tax revenue over GDP. Bruekner (1999) examined the effects of local corruption and tax evasion, and the result of the study showed that corruption limits the benefits of fiscal decentralization through an increase in public goods and lack of fulfillment of demand.

According to James and Gray (2007), corruption in Europe and Central Asia between 2002-2005, has drastically reduced in many countries as a result of systematic effort to fight corruption, including: implementing risk analysis, random audit, strong enforcement and sanctions mechanism as well as reformation of tax laws and policies, leading to improvement in administration efficiency and lower corruption. However, Mustafa and Yilmaz (2006) analyzed the role of internal control in public financial management and asserted that recent reform in developing countries showed that decentralization does not lead to a better result because of corruption, waste, and inefficiencies. Also, Fjeldstad (2003) analyzed the impact of corruption on revenue in Tanzania; the result of the study indicated that revenue has increased as a result of organizational restructuring. Thereafter, corruption increased and the revenue declined. In discussing the demand and supply of corruption in developing countries, Heineman and Heimann (2006) stated that corruption could be mitigated in a number of dimensions, through understanding the cultural problem, which can help to strengthen enforcement and state development.

Wei (1997) examined the effect of corruption induced uncertainty on foreign direct investment (FDI) across nations. Uncertainness was measured according to constructed and unpublished individual survey responses on the level of corruption in the related countries. It was found that both tax rate and corruption have negative effect, are statistically significant and quantitatively large. He further stated that an increase in uncertainty leads to corresponding increase in tax rate of multinational firms. Similarly, Blackburn, Bose, and Haque (2006) focused on corruption among public bureaucrats and its effects on economic development. The result of their study indicated a negative relationship between corruption and development. Based on the above literature on perceived corruption and tax administration 
efficiency, This variable is measured with four items adapted from OECD (2012). Therefore, it is hypothesized in an alternative form that:

H6: There is a significant positive relationship between perceived corruption and tax

administration efficiency.

\section{Research Framework}

The theoretical framework of current study is developed based on extant literature review. The framework consists of six independent variable and a dependent variable. Figure 1 below indicates the direction of the hypothesized relationship between the variables.

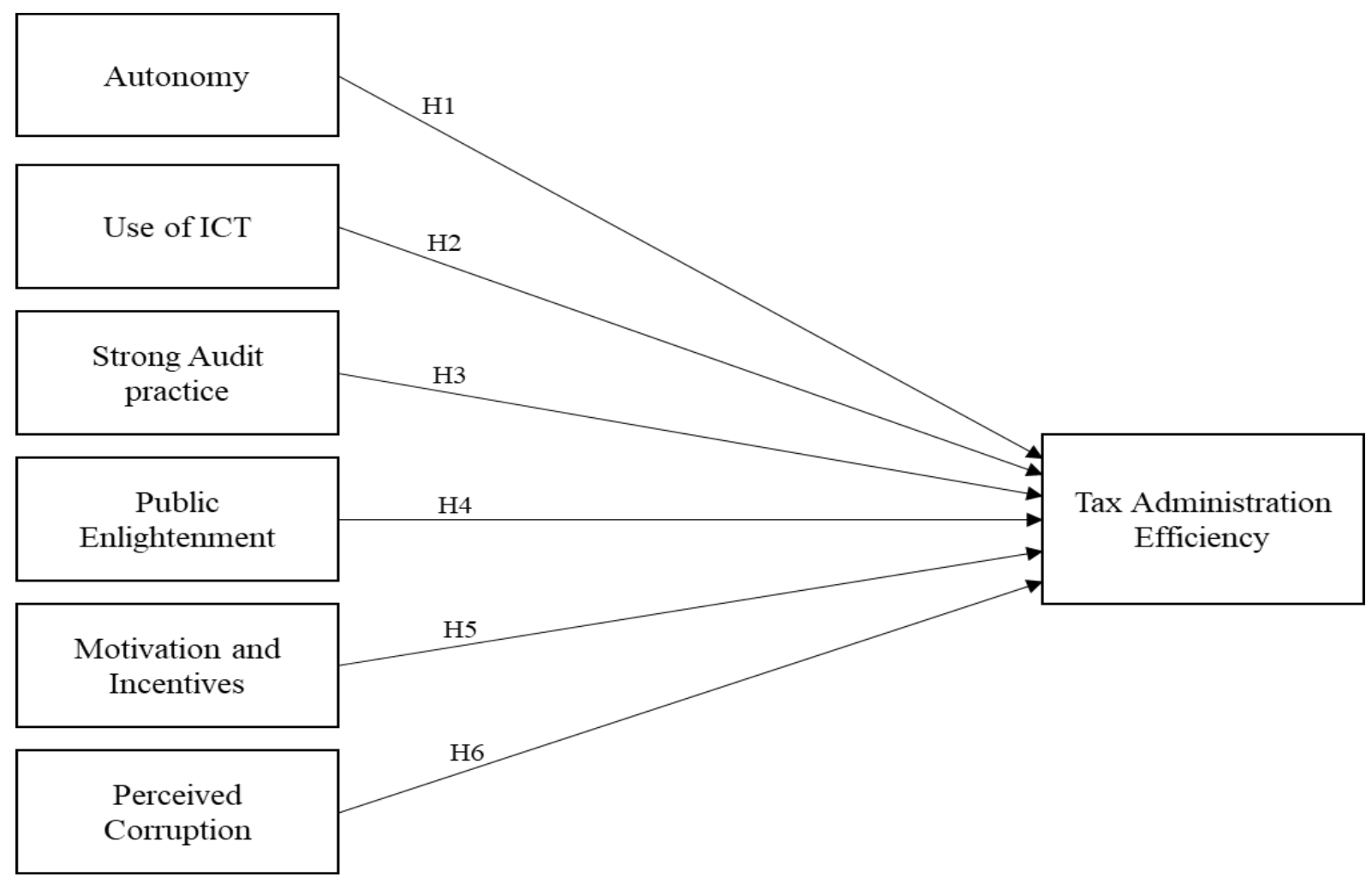

\section{Figure 2.1. Theoretical Framework of Tax Administration Efficiency}

The main gap identified by the current study is that despite many studies have been conducted on tax administration efficiency, there is still a high level of tax defaulters in Nigeria which hinder tax revenue performance. Current statistics indicate that tax contributes $7 \%$ to GDP, which is below the threshold of $15 \%$ for low-income African countries, compared to $22.5 \%$ and over $29 \%$ for medium income and high-income countries, respectively (Okonjo-Iweala, 2013). Nonetheless, previous studies have attempted to investigate tax administrations efficiency using a different set of variables and approaches. For instance, Djawadi and Fahr (2013) and Palil and Ibrahim (2011) used public enlightenment, strong audit practice and use of tax money as determinants of tax compliance behavior and not administration 
efficiency; while Abiola and Asiweh (2012) used ICT and public enlightenment in determining the administrative efficiency of government ministries. In fact, a study that highlighted these variables is that of Micah et al. (2012). However, it is notably clear that most of these studies are conceptual and fragmented. Considering the preceding weakness in past literature, what is lacking now is an integrated framework that would combine the identified factors and evaluates their influence on tax administration efficiency, which current study is set to achieve. Thus, this study provides first empirical evidence on the effect of these variables on tax administration efficiency in Nigeria, by using the Bauchi State Board of Internal Revenue, as a sample.

\section{Research Methodology}

\section{Sample and Data Collection}

The study population consists of the staff of Bauchi BIR. There is 225 staff across the six area offices, including the headquarters in Bauchi, and this comprises 10 top management (the Chairman of the board and nine directors), 25 middle-level managers and 190 supporting managers, from whom the sample of this study was drawn. Based on the population obtained for this research (i.e., 225), the recommended sample size is 144 following Krejcie and Morgan (1970). A simple random sampling was used in the study. This sampling procedure gives the entire respondents an equal chance of being selected.

For gathering the necessary data, a cross-sectional survey method was used, and a structured questionnaire was used for the data collection. The questionnaire consists of two parts, section A comprises questions regarding the variables under study, while Section B consists of the demographic information of the respondents. The current study's constructs used a 5-point Likert scale ranging from 'strongly disagree' (1) to 'strongly disagree' (5) that were derived from previous studies. 5 point Likert scale is the most frequently used scale in research because it captures the extent to which a respondent disagrees or agrees with a statement (Awais, Chee, \& Veera, 2012).

A total of 31 items were used to operationalize the seven constructs in the research framework. Tax administration efficiency construct was measured with four items that were adapted from Abiola and Asiweh (2012). For the autonomy of board of internal revenue construct, six relevant measures were adapted from Abiola and Asiweh (2012), European Union (2007), and Verscheure (2007). For ICT construct, four items were adapted from Upadyaya (2011). Similarly, for strong audit practice and public enlightenment constructs, four relevant measures each were adapted from Badara (2012) and Abiola and Asiweh (2012). The five items used to measure motivation and incentives were adapted from Wright (2004). Also, four items were obtained from OECD (2012) to measure perceived corruption construct. The items for all the seven constructs are included in the appendix. 
A total of 144 questionnaires were distributed to the targeted respondents. Out of 124 surveys returned, 117 representing $81.25 \%$ of the total sample size were valid or usable. Seven questionnaires or approximately five percent of the survey distributed were not included in the analysis as they were incomplete or wrongly filled in by the respondents. In order to test for non-response bias, current study employed extrapolation method where the sample was divided into two group (early and late) in accordance with the suggestions provided by Armstrong and Overton (1977). Specifically, independent $\mathrm{T}$ statistics were used to compare the two groups, i.e., the early respondent and late respondents. The results of the Levene's test for equality of variance between the two groups and significant values for all the variables is greater than .01, thus indicating that there is no significant difference among these groups.

\section{Results and Findings}

\section{Demographic Data}

Statistical Package for Social Sciences (SPSS) was used to determine the sample characteristics. The respondents comprised 100 males representing $85.5 \%$ and 16 females representing $13.7 \%$ while one respondent did not indicate his/her gender. With regards to age, five age groups were involved in this study with a 10-year range in each group with the exception of the above 60 years old group. The age group between 20-30 years had the highest number of responses of 54 representing $46.20 \%$, followed by 49 responses representing about $41.90 \%$ for the age group between $31-40$ years, 13 responses representing $11.10 \%$ for the $41-50$ age group and only one response representing $0.90 \%$ for age group above 60 years.

\section{Assessment of Measurement and Structural model}

A two-fold analysis method was adopted to evaluate the research framework using Smart PLS 2.0. PLS is chosen because of its robustness against multicollinearity and makes no assumptions regarding the distribution of constructs (Cassel, Hakcl, \& Westlund, 2000). It also ensures optimal model prediction accuracy and is suitable for small sample size (Chin, 1998; Hair, Ringle, \& Sarstedt, 2013) such as this one compared to covariance-based structural equation model. Therefore, evaluation of measurement model and the structural model was carried out to investigate the relationship of the determinants. In order to establish the measurement model of this study, we examined the reliability, convergent validity, and discriminant validity for the seven constructs as follows:

Reliability is used to assess the internal consistency of a construct using composite reliability. The reliability of a measure indicate the degree of which the measure is error free, thus, offers consistent result across time and items in the construct. As it can be seen from Table 1, the values for each construct exceed the minimum threshold of 0.60 for exploratory study (Hair Ringle, \& Sarstedt, 2011). Therefore, all the constructs of the current study demonstrate adequate reliability. Next, the study assessed the 
convergent validity which is the extent to which the indicators of a specific construct share a high proportion of variance in common (Sekaran \& Bougie, 2013). The results presented in Table 1 and Table 2 revealed that all the values of item loadings and AVE respectively are above 0.50 which indicate that convergent validity has been established. Discriminant validity which the degree to which two constructs truly differs (Sekaran \& Bougie, 2013). When the square root of the AVE extracted is greater than it correlations with all the other constructs, then it can be concluded that discriminant validity has been established. In Table 2, the results of discriminant validity are presented. 


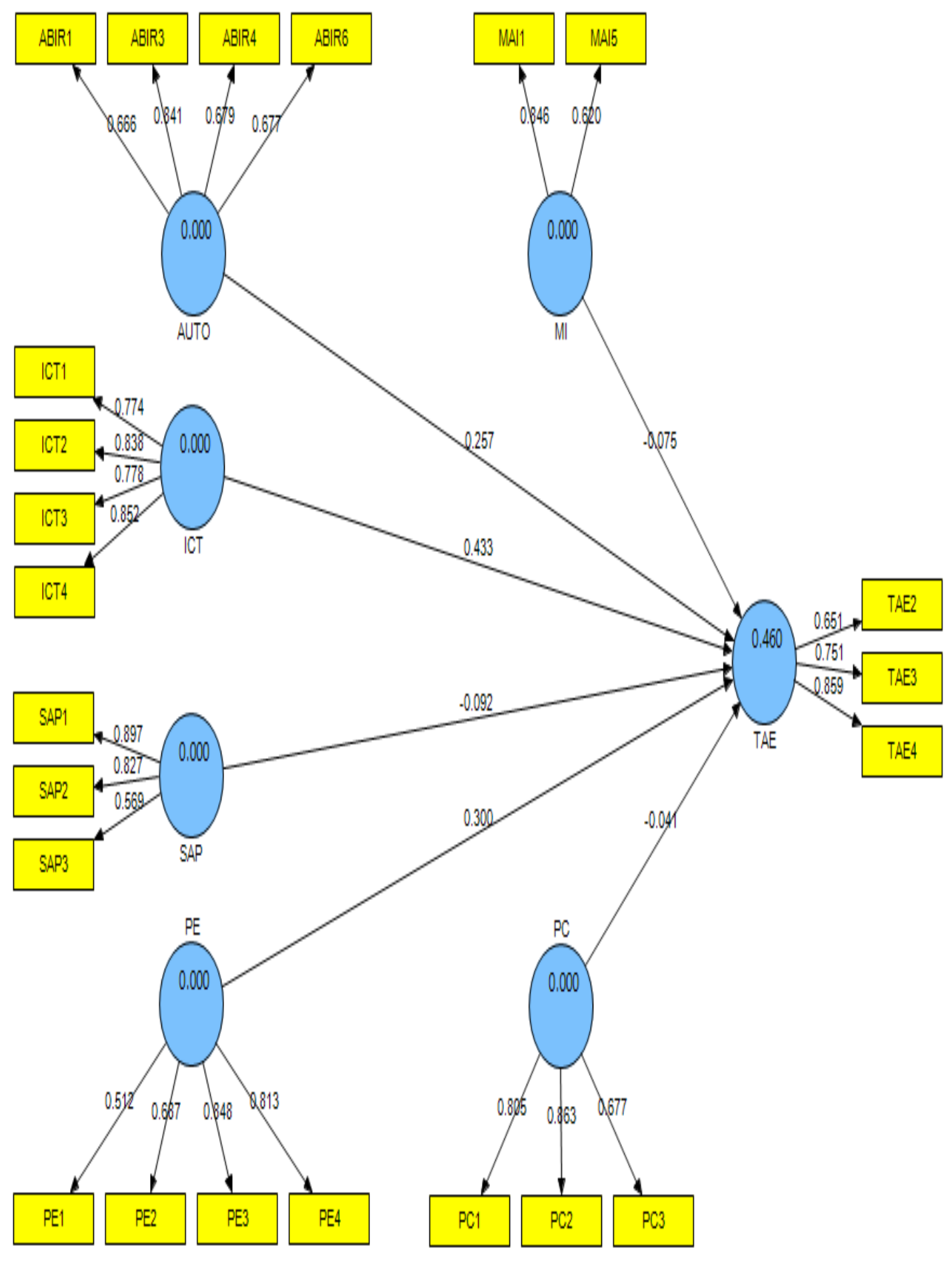

\section{Figure 2. Measurement Model}

Note: $A B I R=$ Autonomy of Board of Internal Revenue; ICT=Information and communication Technology; SAP=Strong Audit Practice; PE=Public Enlightenment; PC=Perceived Corruption; TAE $=$ Tax Administration Efficiency. 
Table 1: Measurement Items Loading and Composite Reliability

\begin{tabular}{lccc}
\hline Constructs & Measurement Items & $\begin{array}{l}\text { Items } \\
\text { Loading }\end{array}$ & $\begin{array}{c}\text { Composite } \\
\text { Reliability }\end{array}$ \\
\hline Tax Admin. Efficiency & & & $\mathbf{0 . 8 0 0}$
\end{tabular}

Tax Admin. Efficiency

0.800

TAE 2

Income generated from tax revenue by my

0.6505

organization has been impressive due to

efficient tax administration.

TAE 3

My organization has adequate

0.7506

infrastructures for efficient tax

administration.

TAE 4

My organization has well-trained staff for

efficient tax administration.

Autonomy

In my opinion our tax administrative

0.809

ABIR 1

structure lack autonomy

ABIR 3

The Board of Internal Revenue has

0.8412

autonomy in recruitment and dismissal of

staff.

ABIR 4

The Board of Internal Revenue has

0.6789

autonomy in budget preparation and

implementation.

ABIR 6

The Board of Internal Revenue has the

autonomy to recruit and dismiss staff.

Use of ICT

0.885

ICT 1

The Board provides me with useful ICT

0.774

training in the daily working procedures.

ICT 2

The Board provides online facility on my

0.8378

desk.

ICT 3

The Board regularly maintained our ICT

0.7777

infrastructures (digital devices, internet

facility).

ICT 4

The Board ensures that our organizational

0.8517

website is well maintained and updated. 


\begin{tabular}{|c|c|c|c|}
\hline SAP 1 & $\begin{array}{l}\text { The board employs strong tax audit to } \\
\text { achieved Targeted Revenue. }\end{array}$ & $\mathbf{0 . 8 9 7 1}$ & \\
\hline SAP 2 & $\begin{array}{l}\text { The Board employs strong tax audit to } \\
\text { solve the problems of tax evasion, } \\
\text { avoidance and other irregularities. }\end{array}$ & 0.8268 & \\
\hline SAP 3 & $\begin{array}{l}\text { The Board employs strong tax audit to } \\
\text { ensure the submission of accurate and } \\
\text { current returns. }\end{array}$ & 0.5694 & \\
\hline Public Enlightenment & & & 0.813 \\
\hline PE 1 & $\begin{array}{l}\text { The Board creates awareness of strong tax } \\
\text { audit to makes the taxpayers render a } \\
\text { satisfactory returns. }\end{array}$ & 0.5122 & \\
\hline PE 2 & $\begin{array}{l}\text { Public enlightenment campaign on } \\
\text { utilization of tax revenue by Board of } \\
\text { Internal Revenue will encourage tax } \\
\text { payment. }\end{array}$ & 0.6873 & \\
\hline PE 3 & $\begin{array}{l}\text { Issuance of tax payment notice in } \\
\text { reasonable time by Board of Internal } \\
\text { Revenue will encourage tax payment. }\end{array}$ & 0.8482 & \\
\hline PE 4 & $\begin{array}{l}\text { Public enlightenment by Board of Internal } \\
\text { Revenue will make people in the informal } \\
\text { sector pay their tax regularly. }\end{array}$ & 0.8129 & \\
\hline $\begin{array}{l}\text { Motivation and } \\
\text { Incentives }\end{array}$ & & & 0.704 \\
\hline MAI 1 & $\begin{array}{l}\text { I have been motivated by my organization } \\
\text { to put my best effort in my job done. }\end{array}$ & 0.8455 & \\
\hline MAI 5 & Time seems to drag while I am on the job. & 0.6198 & \\
\hline \multicolumn{4}{|l|}{ Perceived Corruption } \\
\hline PC 1 & $\begin{array}{l}\text { Board of Internal Revenue explicitly } \\
\text { disallows tax deductions for bribes to } \\
\text { public officials. }\end{array}$ & 0.805 & 0.827 \\
\hline PC 2 & $\begin{array}{l}\text { Board of Internal Revenue raises } \\
\text { awareness among taxpayers that bribes are } \\
\text { not deductible. }\end{array}$ & 0.8632 & \\
\hline PC 3 & $\begin{array}{l}\text { Board of Internal Revenue Staff are } \\
\text { authorized to report suspicions of }\end{array}$ & 0.6766 & \\
\hline
\end{tabular}


Table 2: Discriminants Validity

\begin{tabular}{|c|c|c|c|c|c|c|c|c|}
\hline & AUTO & ICT & MI & PC & PE & SAP & & AVE \\
\hline Autonomy & 0.719 & & & & & & & 0.518 \\
\hline Use of ICT & 0.339 & 0.811 & & & & & & 0.658 \\
\hline Motivation and Incentives & -0.358 & -0.087 & 0.741 & & & & & 0.550 \\
\hline Perceived Corruption & 0.261 & 0.535 & -0.147 & 0.785 & & & & 0.617 \\
\hline Public Enlightenment & 0.180 & 0.235 & 0.251 & 0.207 & 0.727 & & & 0.529 \\
\hline Strong Audit Practice & 0.255 & 0.325 & -0.094 & 0.426 & 0.100 & 0.777 & & 0.604 \\
\hline Tax Adimin. Efficiency & 0.451 & 0.545 & -0.115 & 0.291 & 0.412 & 0.134 & 0.758 & 0.575 \\
\hline
\end{tabular}

\section{Structural Model}

Having established the measurement model of this study, the next step is to perform a structural model to test the hypothesis paths. Current study applied bootstrapping procedure to analyze the significance path of the in this model. Specifically, 5000 bootstrap samples were used (Hair et al., 2012). The results revealed by the bootstrapped cases is presented in Figure 3 below. 


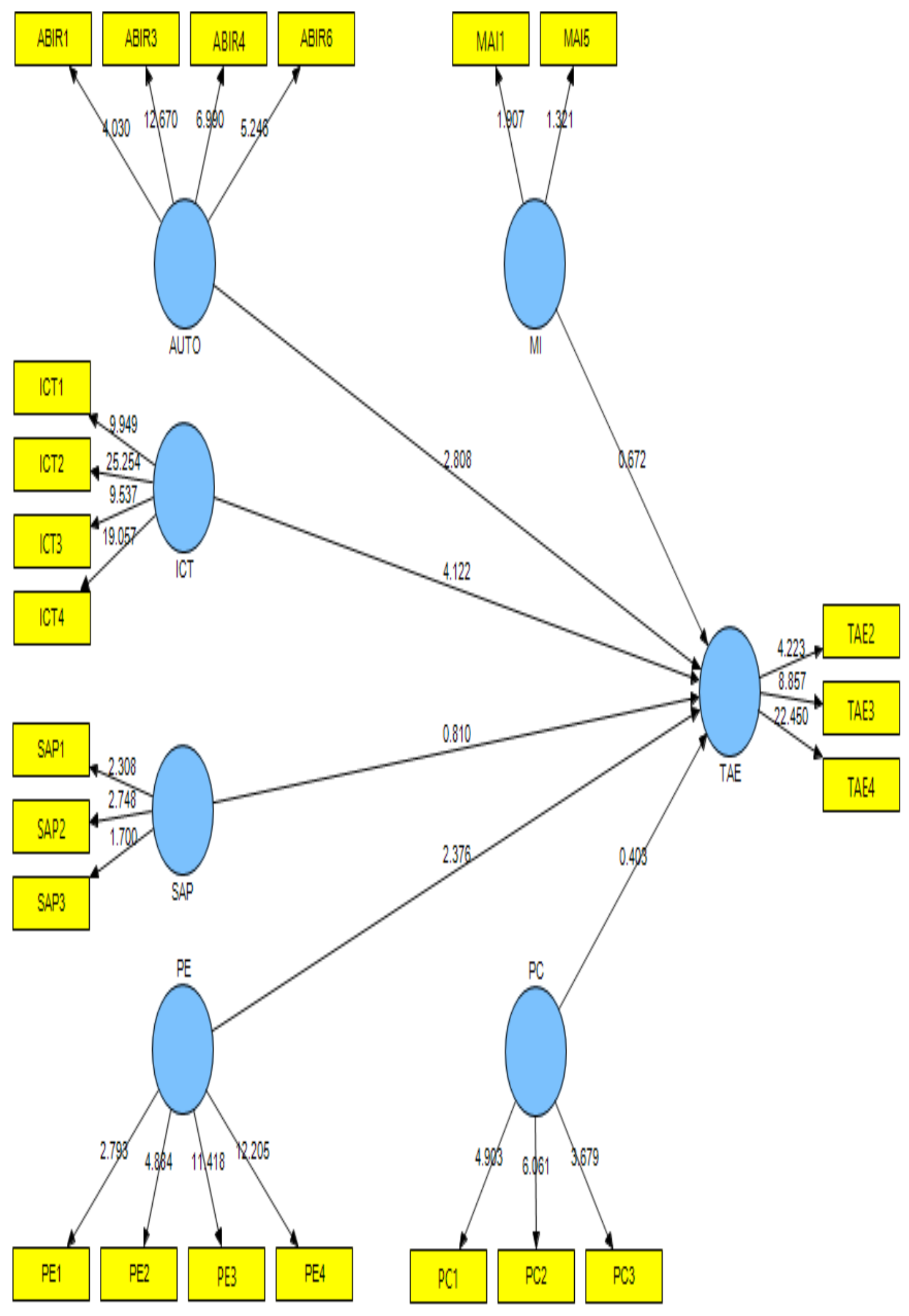

\section{Figure 3. Structural Model}

The findings have been explained taking into cognizance of the beta values, standard error, and $\mathrm{T}$ statistics. Then were made based on the significance of the coefficients values as shown in Table 3 . 
Table 3. Test of Significance paths

\begin{tabular}{lccccl}
\hline Relationship & Beta & Stand Error & T Stat & P Value & Decision \\
\hline AUTO -> TAE & 0.257 & 0.092 & 2.808 & 0.01 & Supported \\
ICT -> TAE & 0.433 & 0.105 & 4.122 & 0.00 & Supported \\
MI -> TAE & -0.075 & 0.111 & 0.672 & 0.50 & Not Supported \\
PC -> TAE & -0.042 & 0.103 & 0.403 & 0.69 & Not Supported \\
PE -> TAE & 0.300 & 0.126 & 2.376 & 0.02 & Supported \\
SAP -> TAE & -0.092 & 0.114 & 0.810 & 0.42 & Not Supported
\end{tabular}

Note: $* \mathrm{t}>1.960, \mathrm{p}<0.05 ; * * \mathrm{t}>2.576, \mathrm{p}<0.01 ; * * * \mathrm{t}>3.291, \mathrm{p}<0.001$

Based on the findings revealed in Table 3, the effect of autonomy on tax administration efficiency has been tested, and the results reveal that beta value is $(\beta=0.257)$, and $p$-value $(p=0.01)$ indicating a significant effect of autonomy on tax administration efficiency. Also, the results of the analysis revealed that ICT is significantly related to tax administration efficiency as indicated by beta value ( $\beta=0.433$ ), and $p$-value of $(p=0.00)$. The findings of the study also revealed that Motivation and incentive is not a statistically significant predictor of tax administration efficiency as revealed by the beta value $(\beta=-$ $0.075)$ and $p$-value of $(p=0.50)$. Furthermore, the effect of perceived corruption on tax administration efficiency with a beta value of $(\beta=-0.042)$ and $p$-value of $(p=0.69)$ indicates statistically insignificant effect between perceived corruption and tax administration efficiency. The effect of public enlightenment on tax administration efficiency has been tested the findings reveals that beta value is ( $\beta$ $=0.300)$, and $\mathrm{p}$-value $(\mathrm{p}=0.02)$ indicating a significant effect of public enlightenment and tax administration efficiency. The results also reveal that strong audit practice is not statistically significant predictor of tax administration efficiency as reveals by beta value $(\beta=-0.092)$ and a $p$-value of $(p=$ $0.42)$.

\section{Discussion of Findings}

The main purpose of this study is to examine the determinants of tax administration efficiency in the context of Nigeria. The results of the structural model analyses for this study extends our understanding of the determinants of tax administration efficiency in the context of Nigeria. The research finding revealed that autonomy of the board of internal revenue has a positive relationship with tax administration efficiency. This finding implies that SBIR has been granted autonomy regarding the recruitment and dismissal of staff, budget preparation, and implementation. Thus, this might lead to an efficient tax administration processes that would result in increased revenue generation, enhancement of economic growth and development and ensuring economic stabilization across the state and the country in general. This finding is in line with the work of London (2010) which shows that there is a positive relationship between autonomy and the efficiency of the administration, which increases 
utilization of human resources, generation of revenue and also facilitates decision-making. The study by Cekmecelioglu et al. (2011) also found that autonomy has a positive relationship with both administrative efficiency and creativity. This is in line with Gammelgaard et al. (2012) study, which found that autonomy increased administrative performance and facilitated administration of interdepartmental relationship, which eventually influences efficiency of the tax system. Furthermore, autonomy increases the quality of services, reduces bureaucracy in implementing management actions as well as improves administration efficiency (Evelyn \& Luzira, 2004). Likewise study by Lubua (2014), found that autonomy is positively linked with tax administration efficiency. Thereby increasing the collection of tax revenue and facilitates economic growth of the current economy.

Besides, ICT has positive impact on tax administration efficiency. This finding implies that users believed that the use of ICT allows the SBIR to improve operational effectiveness and efficiencies. The finding further suggests that the use of ICT enhanced work quality enables the revenue officers to solve complex problems and helps in integration of all departments. This finding concurs with previous research by Idisemi and Ann (2011), who found that ICT facilitates effective and efficient communication between the tax officers and taxpayers regardless of time and distance; enables the revenue collection officers to manage data relating to taxpayers efficiently, reduces costs and saves time. The findings of Buseni (2013) support current study result; their findings revealed that the use of ICT increases innovation, productivity, efficient practices and improves the overall taxation processes of the government. Similarly, Edmead et al. (2013) found the use of computer and other electronic gadgets enhances service delivery and increases administrative efficiency of the government businesses. Also, this result is consistent with Stiphen (2015), who point out the importance of ICT adoption in taxation processes in Nigeria. Moreover, Lubua (2014) found that ICT has positive relationship with tax administration efficiency. The successful implementation of ICT improves the delivery of public services and dissemination of tax administration information to general public. It also enable revenue officers to efficient carried out their day to day operations. Thus, increasing revenue generation for the government.

However, the result of revealed insignificant relationship between strong audit practice and tax administration efficiency. Our findings are different from those of past studies (e.g., Alm \& Mckee, 2006; Dubin, 2006; Badara, 2012). Although there are awareness programmes by the board to encourage prompt and satisfactory tax returns, taxpayers evade submission of accurate tax returns to the tax authority. One of the possible explanation for this results may be due to prior knowledge of taxpayers that they will not be audited. This attitude of the taxpayers may adversely affect the revenue generation of the state, thus leading to tax administration inefficiency. In line with current study results research have indicated that average Nigerians are tax evaders and avoiders (Ebimobowei \& Peter, 2013). 
As for the public enlightenment, findings from this study revealed a significant positive relationship between public enlightenment and tax administration efficiency. This finding Public enlightenment enables taxpayers to understand that payment of tax is a responsibility and not just a matter of giving and take. This will increase compliance with tax payment and boost revenue generation for the government. This is supported by Nwanna and Richards (2010), who studied the importance of basic tax education among US citizens. They found that enlightened citizenry is comparatively less averse to taxes, less rebellious to government policies with regards to tax matters, less hostile to the IRS and more compliant. These eventually lead to increased government revenue and efficient tax administration. In supports of this findings, Smith (2011) noted that proper awareness programme could lead to efficiency and effectiveness of public administration. Consequently, increasing the internally generated revenue of the state in particular and the country at large. Enlightened taxpayers reduce firms ${ }^{\text {ee }}$ misconceptions about tax policies and procedures, and educate them on the importance of keeping proper records (Rahman, 2009). Williams (2013) identified increased public awareness as a critical factor that encourages taxpayers to comply with tax legislation. Another study that corroborated this finding is that of Olowo-Okere et al. (2013) which found that public enlightenment program on tax revenue accountability has a significant influence on tax. Increase in awareness of tax law is positively related with the extent to which taxpayers voluntarily files their tax return to the government (Lubua, 2014). Similarly, Eriksen and Fallan (1996) documented that awareness of tax law is important for preferences and attitudes towards taxation. While motivation and incentives are reported to have an insignificant relationship on tax administration efficiency. Motivation and incentives which is usually believed as an important factor for enhancing employees performance in the organization have been considered in current study. However, finding from the SBIR indicated that motivational factors, such as encouragement, remuneration, and wages do not lead to tax administration efficiency. Thus, a need exists for further study using different measures to investigate the matter. Nonetheless, this finding is consistent with the study by Anderson (2009) which found that public service motivation is not a major determinant of organizational efficiency.

Also, the results of current study revealed insignificant relationship between perceived corruption and tax administration efficiency. One possible reason for this finding may due to new policies implemented by the state government regarding tax collections and disbursements, which lead to a reduction in corruption and irregularities of the board. This finding is supported by the work of Dreher and Schneider (2010) found that there is insignificant relationship between corruption and shadow economy when perception based-indices are used. Also, Brasoveanu and Brasoveanu (2009) showed that there is insignificant relationship between corruption and tax revenue over GDP. Furthermore, prior studies found that there is negative relationship between corruption and tax administration efficiency (Lubua, 2014; Nawaz, 2010), the presence of corruption reduces the revenues of government. Thereby hindering economic growth of a nation. However, the result of current study differs from previous research (e.g., 
Karimi et al., 2010; Ogbonna, 2011) possibly due to the perceptual measures used in measuring the construct. Therefore, there is need to conduct further research using different measures, subjects, and research contexts.

In a nutshell, the findings of current study would be of benefits especially to the Nigerian government. In addition, other African countries such as Algeria, Angola, Libya, and South Africa which are considered as the largest economies in Africa (African Economic Outlook, 2015), might use the findings in developing strategies that minimize non-compliance and ensure tax administration efficiency. Thereby, leading to steady revenue generations that would allow the government to carried out it administrative activities, adequate service provision to the citizens, and speedy infrastructural and economic development.

\section{Conclusion}

Tax, as a key tool for governments to raise revenue, has a great impact on the economic growth and development of a country. There is a continued recognition of the role that the tax system plays in enhancing national development and promoting good governance. Therefore, the need for an efficient tax administration is vital to any country's well-being. However, the Nigerian tax administration is faced with challenges which make it inefficient, as a result of high level of tax defaulters in the country. But there is limited research in Nigerian in order to improve the situation. Thus, this motivated current study to investigate the key drivers that might lead to efficient tax administration system in Nigeria. The findings of the study provide evidence for confirming a significant relationship among three major constructs. The findings were drawn based on statistical evidence and recommendation was logically drawn from the findings. Firstly, the results revealed that autonomy is significantly related to tax administration efficiency. This implies that for government to improve the current situation of high tax defaulters, they should be more concerned with the developing strategies that would grant autonomy to BIR in order to improve revenue performance. Furthermore, based on the empirical evidence, it has been established that there is a significant positive relationship between use of ICT and tax administration efficiency. This implies that the higher the usage of ICT the better the efficiency and effectiveness of tax administration process. Therefore, policymaker should encourage the adoption and implementation of ICT in all the operational activities of the tax administration. Such policy would enable BIR to optimally benefit from the use of ICT more especially in the process of tax assessment, collection, and accounting of all taxes. Another finding that has important policy implications is the positive relationship between public enlightenment and tax administration efficiency. Administrators should embark on strong campaign on the need for taxpayers to fulfil their obligation, to enable the government to finance public expenditure and development so as to enhance the general welfare of its citizens. Finally, the government should ensure that tax defaulters, especially the economic and political 
elites and informal sector are made to pay taxes due. Adequate and effective monitoring and supervision of tax administration performance indicators in order to establish a culture of transparency and accountability in the tax system are essential.

Although current study has reported significant findings in the context of SBIR, several limitations were identified; first, this study is the first empirical study on the determinants of tax administration efficiency in Bauchi, Nigeria. Therefore, there is a need to conduct more studies in order to examine the relationship between autonomy, ICT, strong audit practice, public enlightenment, motivation, and incentives, as well as perceived corruption and tax administration efficiency. This would enable confirmation or otherwise of the findings of this study. Secondly, this study focuses only on tax administrators, i.e., staff of Bauchi Internal Revenue. Hence, it is recommended that future studies should include taxpayers ${ }^{\text {ee }}$ and other stakeholders ${ }^{\text {ee }}$ views. Thirdly, the geographical location of this study is Bauchi; future studies should consider other states or regions of the country in order to have an indepth understanding of this phenomenon. Finally, future studies may also consider other factors, such as non-availability of tax statistics, a multiplicity of taxes, underground economy, regulatory challenges and government spending (Micah et al., 2012).

\section{References}

Abiola, J., \& Asiweh, M. (2012). Impact of tax administration on government revenue in a developing economy - A case study of Nigeria. International Journal of Business and Social Science, 3(8).

Adeosun, O. (2010). Quality basic education development in Nigeria: Imperative for the use of ICT, Journal of International Cooperation in Education, 13(2), 199-211.

African Development Bank Group (2015). Youth empowerment, access to energy and gender equality. Centurion, Gauteng, South Africa.

Afful-Broni, A. (2012). Relationship between motivation and job performance at the University Mines and Technology, Tarkwa, Ghana: Leadership lessons. Creative Education, 3(3), 309-314. doi: http://dx.doi.org/10.4236/ce.2012.33049

Akintoye, I. R., \& Tashie, G. A. (2013). The effect of tax compliance on economic growth and development in Nigeria, West Africa. British Journal of Arts and Sciences, 11(II), 222-231.

Alm, J., \& Mckee, M. (2006). Audit certainty, audit productivity, and taxpayer compliance. Working paper 06-043.

Alon, A., \& Hageman, A.M. (2013). The impact of corruption on firm tax compliance in transition economies: whom to trust? J Business Ethics. 116, 479-494.

Anderson, (2009). What determine the behaviour and performance of health professionals? Public service motivation, professional norms, and/or economic incentives. International Review Administrative Sciences, 75, 79-97.

Antomioni, D. (1999). What motivates middle managers? Industrial Management, 41(6),27-30. 
Anyaduba, J. O., \& Modugu, K .P. (2013). Tax audit and tax compliance in Nigeria. Asian Journal of Research in Business Economics and Management, 3(9), 227-240.

Armstrong, J., \& Overton, T. (1977). Estimating nonresponse bias in mail surveys. Journal of Marketing Research, 14,396-402.

Asada, D. (2005). The administration of personal income tax in Nigeria: Some problem areas. Working paper, University of Jos.

Association of Colleges (2008). Improving administrative efficiency in colleges. A paper from the Association of colleges.

Awais, M. B., Chee, H. H., \& Veera, K. S. (2012). A Guide to Beginners: Data Analysis using SPSS and AMOS. Pearson Malaysia Sdn Bhd. Malaysia: Pearson.

Badara, M. S. (2012). The effect of tax audit on compliance in Nigeria: (A study of Bauchi state board of internal revenue). Research Journal of Finance and Accounting, 3(2), 74-79.

Barone, G., \& Mocetti, S. (2009). Tax morale and public spending inefficiency.

Blackburn, K., Bose, N., \& Haque, M. E. (2006). The incidence and persistence of corruption in economic development. Journal of Economic Dynamics \& Control, 2447-2467.

Brasoveanu, I. V., \& Brasoveanu, L. O. (2009). Correlation between corruption and tax revenues in EU 27.

Bruekner, J. K. (1999). Fiscal decentralization in developing countries: The effects of local corruption and tax evasion. CEMA Working paper series, 1, 1-18.

Cantens, T., Raballand, G., \& Bilangna, S. (2010). Reforming customs by measuring performance: A Cameroon case study. World Customs Journal, 4(2), 55-74.

Cassel, C.M., Hakcl, P., \& Westlund, A.H. (2000). On measurement of intangible assets: A study of robustness of partial least squares. Total Quality Management, 11(7), 897-908.

Cekmecelio, H.G., \& Gunse, A. (2011). Promoting creativity among employees of mature industries: The of autonomy and role stress on creative behaviors and job performance. Procedia Social and Behavioral Science, 24, 889-895. Retrieved from: www.sciencedirect.com

Chan, C.W., Troutman, C.T., \& O'Bryan, D. (2000). An expanded model of taxpayer compliance: Empirical evidence from United States and Hong Kong. Journal of International Accounting, Auditing and Taxation, 9(2), $83-103$.

Chin, W. W. (1998). The partial least squares approach to structural equation modeling. Modern Methods for Business Research, 295(2), 295-336.

Crandall, W. (2010). Revenue administration: Autonomy in tax administration and the revenue authority model.

Croxton, R., \& Moniz, R. (2009). An analysis of employees motivation within the public sector.

Decman, M., Stare, J., \& Klun, M. (2010). E-government and cost-effectiveness: E-taxation in Slovenia. Transylvanian Review of Administrative Sciences, 31, 48-57. 
David-West, J.O. (2013, May). Oil and gas and other mineral taxation. A paper presented at the special training programme of the chartered institute of taxation of Nigeria, Nigeria.

Djawadi, B.M., \& Fahr, R. (2013). The impact of tax knowledge and budget spending influence on tax compliance. Discussion paper no. 7255.

Dobre, O. (2013). Employee motivation and organizational performance. Review of applied socioEconomic Research, 5(1), 53-60.

Dubin, J.A. (2006). The effect of audit rates on the federal individual income tax, 1987-2004.

Dreher, A., \& Schneider, F. (2010). Corruption and the shadow economy: An empirical analysis.

Public Choice, 144, 215-238. doi 10.1007/s11127-009-9513-0.

Edmead, N., Ngwu, C., Oqua, B. I., \& Pichel, F. (2013). Streamlining land administration and governance in Cross River State, Nigeria.

Erard, B. (1994). Honesty and evasion in the compliance game. The RAND Journal of Economics, 25(1), $1-19$.

Evelyn, A., \& Luzira, M. (2004). Autonomy of apex hospitals in Uganda: Too little, too slow health policy and development. 2(2), 151-160.

Fagbemi, O. T., Uadile, O. M., \& Noah, A. O. (2010). The ethics of tax evasion: Perpetual evidence from Nigeria. European Journal of Social Sciences, 17(3), 360-371.

Federal Inland Revenue Service (2013, April 9). Nigeria's chaotic tax system. Punch Editorial Board.

Federal Inland Revenue Service (2009). Performance appraisal in 2008 and work plan for 2009. Abuja Federal Inland Revenue Service.

Fjeldstad, O. (2003). "Fighting fiscal corruption: Lessons from the Tanzania revenue authority, Public Administration and Development, 23(2), 165-175.

Garde, M. P. (2004, November 15). A model for tax administration reform. Business focus bulletin.

Gammelgaard, J., Mcdonald, F., Stephan, A., Selmann, H.T., \& Christopher, D.R. (2012). The impact of increase in subsidiary autonomy and network relationships on performance. International Business Review, 21, 1158-1172.

Gcabo, R., \& Robinson, Z. (2007). Tax compliance and behaviour response in South Africa: An alternative investigation. SAJEMS NS, 10(3), 357-370.

Gordon, R., \& Li, W. (2009). Tax structure in developing countries. Many puzzles and possible explanation. Journal of Public Economics, 93(7-8), 855-866.

Hair, J. F., Ringle, C. M., \& Sarstedt, M. (2011). PLS-SEM: Indeed a Silver Bullet. The Journal of Marketing Theory and Practice, 19(2), 139-152.

Hair, J. F., Ringle, C. M., \& Sarstedt, M. (2013). Partial Least Squares Structural Equation Modeling: Rigorous Applications, Better Results and Higher Acceptance. Long Range Planning, 46(1-2), $1-12$. 
Hansford, A., \& Hasseldine, J. (2003). Tax auditing under the self-assessment: Survey evidence from the United Kingdom. New Zealand Journal of Taxation Law and Policy, 9, 171-83.

Hassan, A. G. D. (2012). Tax administration in Kano state: problems and prospects. International Journal of Arts and Commerce, 1(3).

Hasseldine, J., Hite, P., James, S., \& Toumi, M. (2007). Persuasive communications: Tax compliance enforcement strategies for sole proprietors. Contemporary Accounting Research, 24(1), 171-94.

Heineman, B.W., \& Heimann, F. (2006). The long war against corruption. Foreign Affairs, 20(1).

Idisemi, A., \& Ann, L. (2011). The benefits of ICT adoption: An empirical study of Nigerian SMEs. Proceedings of the European Conference on Information Management, 483.

International Telecommunication Union (2012). Sustainable ICT in corporate organizations.

James, B. (2013). Effects of information and communication technology on secretaries' performance in contemporary organizations in Bayelsa state, Nigeria. Information and Knowledge Management, 3(5), 87-93.

James, A. H., \& Gray, C. W. (2007). Policies and corruption outcomes in anticorruption in transition 3. Who is succeeding and why? The World Bank.

Joon, K. K., \& Kim, K. S. (2011). Tax administration reform in Korea and its implications. World Bank and KDI School Conference on Fiscal Policy and Management on 14-18 November2011.

Karimi, S. P., Jafari, S. A., \& Rezaei, R. A. (2010). Corruption and tax revenue new evidence from developing countries. Australian Journal of Basic and Applied Sciences, 4(9), 218-232.

Kawai, N., \& Strange, R. (2013). Subsidiary autonomy and performance in Japanese multinationals in Europe. International Business Review.

Kiabel, D. B., \& Nwokah, G. N. (2009). Boosting revenue generation by state governments in Nigeria: The tax consultant option revisited. European Journal of Sciences, 8(4).

Kleven, H., Knudsen, M. B., Kreiner, C. T., Pedersen, S., \& Saez, E. (2010). Unwilling or unable to cheat? Evidence from a randomized tax audit experiment in Denmark. Working paper.

Krejcie, R. V., \& Morgan, D. W. (1970). Determining sample size for research activities. Educational and Psychological Measurement, 30, 607-610.

London, J. D. (2013). The promises and perils of hospital autonomy reform by decree in Vietnam, social science and medicine. 232-240. doi: http://dx.doi.org/10.1016/j.socscimed.2013.07.009

Lubua, E.W. (2014). Influencing tax compliance in SMEs through the use of ICT. International Journal of Learning, Teaching and Educational Research, 2(1), 80-90.

Machupa, O., Otaigo, E., Koloseni, D., \& Shimba, F. (2011). Assessing the factors influencing information technology investment decisions: A survey of sampled public sector organizations in Tanzania. ICIEIS, 1(251), 385 -399.

Manasan, R. G. (2003). Tax administration reform: (Semi-) autonomous revenue authority anyone? Philippine institute for development studies. Discussion paper series no. 2003-05 (revised). 
Manzoor, Q. (2012). Impact of employees motivation on organizational effectiveness. Business Management and Strategy, 3(1). doi:10.5296/bms.v3i1.904

Marsden, D., \& Richardson, R. (1992). Motivation and performance related pay in the public sector: A case study of the Inland Revenue. Centre of economic performance, London School of Ecomomics, Discussion paper No. 75, May.

Marziana H., Mohamad, N.orkhazimah A., \& Mohmad, S. D. (2010). Perceptions of taxpayers with level of compliance: A comparison in the east coast region, Malaysia. Journal of Global Business and Economics, 1(1), 241-257

Micah, L. C., Ebere, C., \& Umobong, A. A. (2012). Tax system in Nigeria - challenges and the way forward. Research Journal of Finance and Accounting, 3(5), 9-15.

Mikesell, J.L. (2003). International experiences with administration of local taxes: A review of practices and issues prepared for the world bank thematic group on taxation and tax policy.

Mustafa, B., \& Yilmaz, S. (2006). Keeping an eye on subnational governments: Internal control and audit at local levels. The World Bank.

Nawaz, F. (2010). Exploring the relationship between corruption and revenue. Transparency international, 1-5.

Ngama, Y. (2013, May 17). 350,000 Companies in Nigeria do not pay taxes, says FG. The Nigerian Voice.

Nwanna, G., \& Richards, D. (2010). The imperative of basic tax education for citizens. American Journal of Business Education, 3(9), 61-66.

OECD. (2012). Tax administration: Detecting corruption. CleanGovBiz.

OECD. (2001). Committee of fiscal affairs forum on strategic management, principles of good tax administration: Centre for tax policy and administration.

OECD. (2011). Efficiency of tax administrations. In government at a glance 2011, OECD Publishing. doi: http://dx.doi.org/10.1787/gov_glance-2011-64-en

Ogbonna, G. N. (2011). Burning issues and challenges of the Nigerian tax systems with analytical emphasis on petroleum profit tax.

Ojochgwu, W.A., \& Stephen, A.O. (2012). Factors that affect tax compliance among small and medium enterprises (SMEs) in north central Nigeria. International Journal of Business Managent, 7(12), 87-96.

Okonjo-Iweala, N. (2013, March 25). Tax emerges as crucial issue in post- 2015 development talks. The Guardian.

Olowookere, J. K., \& Fasina, H. T. (2013). Taxpayers' education: A key strategy in achieving voluntary compliance in Lagos state, Nigeria. European Journal of Business and Management, 5(10), 146154.

Onyeukwu, H. (2010). Business tax in Nigeria: The controversy of multiple taxation. Corporate governance.

Osinbajo, Y. (2017, June 30). Osinbajo reads riot act to tax defaulters. Vanguard Nigeria. 
Retrieved from: http://www.vanguardngr.com/2017/06/osinbajo-reads-riot-act-tax-defaulters2/

Palil, M. R., \& Mustapha, A. F. (2011). Determinants of tax compliance in Asia: A case of Malaysia. European Journal of social Sciences, 24(1), 7-32.

Rahman, A. (2009). Investment climate in practice: Tackling corruption through tax administration reform.

Ramot. I. A. L., \& Ichihashi, M. (2012). The effects of tax structure on economic growth and income inequality. IDEC discussion paper Hiroshima University. Japan.

Randlane, K. (2012). Tax compliance and tax attitudes: The case of Estonia. Journal of Management and Change, 29, 89-103.

Rainey, H. G., \& Steinbauer, P. (1999). Galloping elepants: Developing elements of a theory of effective government organizations. Journal of Public Administration Research and Theory, 9(1), 1-32.

Sanni, A. (2012). Multiplicity of taxes in Nigeria: Issues, problems and solutions. International Journal of Business and social Sciences, 3(17), 229 -236.

Sekaran, U., \& Bougie, R. (2013). Research methods for business: A skill building approach (6th ed.). West Sussex: John Wiley \& Sons Ltd.

Serkan B., Tamer, B., Yüzba ${ }_{s}$ B. \& Mohdali, R. (2016). The impact of religiosity on tax compliance among Turkish self-employed taxpayers, Religions. The Social Sciences, 7(2), 37-39.

Smith, M. L. (2011). Limitation of building institutional trustworthiness through e-government. A comparative study of two e-services in Chile. Journal of Information Technology, 26, 78-93.

Solomon, O., Hashim, N. H., Mehdi, Z. B. T., \& Ajagbe, M. A. (2012). Employee motivation and organizational performance in multinational companies: A study of Cadbury Nigeria plc. International Journal of Research in Management \& Technology, 2(3), 303-312.

Stephen, O. (2015). A causality analysis between tax compliance behaviour and Nigerian economic growth. Mediterranean Journal of Social Sciences, 6(1), 577-582. doi:10.5901/mjss.2015.v6n1s1p577

Stephen, A. O., Ayodotun, I., Iyoha, F. O., Charles, K. A., \& Deniel, G. (2017). Role of e-Governance in Nigerian tax system: Strategy perspective to enhance compliance. The Social Sciences, 12(8), 1482-1486.

UN. (2000). Improving tax administration in Sub-Saharan Africa: The potential of revenue agencies and electronic service delivery.

Upadhyaya, G. (2011). ICT application in service delivery: A case of inland revenue department, Nepal. A Thesis submitted to the school of postgraduate study. North South University, Bangladesh.

Verschuere, B. (2007). Measuring policy autonomy of public organizations: Conceptual and methodological issues. Paper for COBRA, Rotterdam, 29-30 March 2007.

Wei, S. L. (1997). Why corruption is much more taxing than tax? Arbitrariness kills. National bureau of economic research. Working paper 6255. 
Williams, I.T. (2013). Effective publicity and education campaigns to enhance compliance: Design and implementation issues. Dominica.

Wright, B.E. (2004). The role of work context in work motivation: A public sector application of goal and social cognitive theories. Journal of Public Administration Research and Theory, 14(1), 5978. doi: 10.1093/jopart/muh004

\section{APPENDIX \\ QUESTIONNAIRE}

Please indicate the extent to which you agree or disagree to each of the statement below, use the scale below to indicate your answer.

\section{1-Strongly disagree (SD) 2-Disagree (D) 3-Not sure (NS) 4-Agree (A) 5-Strongly Agree (SA)}

\begin{tabular}{|c|c|c|c|c|c|c|}
\hline & & $\mathrm{SD}$ & $\mathrm{D}$ & NS & A & SA \\
\hline 1. & In my view our tax system has an efficient collection process & 1 & $\overline{2}$ & $\overline{3}$ & $\overline{4}$ & $\overline{5}$ \\
\hline 2. & $\begin{array}{l}\text { Income generated from tax revenue by my organization has } \\
\text { been impressive due to efficient tax administration }\end{array}$ & 1 & 2 & 3 & 4 & 5 \\
\hline
\end{tabular}

3. My organization has adequate infrastructures for efficient tax $\begin{array}{llllllll}1 & 2 & 3 & 4 & 5\end{array}$ administration

4. My organization has well-trained staff for efficient tax $\quad \begin{array}{llllllll}1 & 2 & 3 & 4 & 5\end{array}$ administration

5. In my opinion our tax administrative structure lack $\quad \begin{array}{lllllll}1 & 2 & 3 & 4 & 5\end{array}$ autonomy

6. Politicians interferes too much with the activities of Board of $\begin{array}{lllllll}1 & 2 & 3 & 4 & 5\end{array}$ Internal Revenue

7. The Board of Internal Revenue has autonomy in recruitment $\begin{array}{lllllll}1 & 2 & 3 & 4 & 5\end{array}$ and dismissal of staff

8. The Board of Internal Revenue has autonomy in budget $\quad \begin{array}{lllllll}1 & 2 & 3 & 4 & 5\end{array}$ preparation and implementation

9. The Board of Internal Revenue takes most of the decisions $\begin{array}{lllllll}1 & 2 & 3 & 4 & 5\end{array}$ itself after consulting the Ministry of Finance

10. The Board of Internal Revenue has the autonomy to recruit $\begin{array}{lllllll}1 & 2 & 3 & 4 & 5\end{array}$ and dismiss staff

11. The Board provides me with useful ICT trainings in the $\begin{array}{lllllllll}1 & 2 & 3 & 4 & 5\end{array}$ daily working procedures

12. The Board provides online facility in my desk $\quad \begin{array}{lllllll}1 & 2 & 3 & 4 & 5\end{array}$ 
13. The Board regularly maintained our ICT infrastructures

$\begin{array}{lllll}1 & 2 & 3 & 4 & 5\end{array}$
(digital devices, internet facility)

14. The Board ensure that our organizational website is well $\quad \begin{array}{lllllll}1 & 2 & 3 & 4 & 5\end{array}$ maintained and updated

15. The board employs strong tax audit to achieved Targeted $\begin{array}{llllllll}1 & 2 & 3 & 4 & 5\end{array}$ Revenue

16. The Board employs strong tax audit to solve the problems of $\begin{array}{llllll}1 & 2 & 3 & 4 & 5\end{array}$ tax evasion, avoidance and other irregularities

17. The Board employs strong tax audit to ensure the submission $\begin{array}{lllllll}1 & 2 & 3 & 4 & 5\end{array}$ of accurate and current returns

18. The Board creates awareness of strong tax audit to makes the $\begin{array}{llllll}1 & 2 & 3 & 4 & 5\end{array}$ taxpayers render a satisfactory returns

19. Public enlightenment campaign on utilisation of tax revenue $\begin{array}{lllllll}1 & 2 & 3 & 4 & 5\end{array}$ by Board of Internal Revenue will encourage tax payment

20. Issuance of tax payment notice in reasonable time by Board $\begin{array}{lllllll}1 & 2 & 3 & 4 & 5\end{array}$ of Internal Revenue will encourage tax payment

21. Public enlightenment by Board of Internal Revenue will make people in the informal sector pay their tax regularly

22. Public enlightenment campaign by Board of Internal Revenue on sanctions and penalty for noncompliance will encourage tax payments

23. I have been motivated by my organization to put my best $\begin{array}{lllllllll}1 & 2 & 3 & 4 & 5\end{array}$ effort in my job done

24. I have been remunerated for staying beyond the working $\quad \begin{array}{llllllll}1 & 2 & 3 & 4 & 5\end{array}$ hours to finish my daily routine task

25. Employees in my organization work as hard as employees in $\begin{array}{lllllll}1 & 2 & 3 & 4 & 5\end{array}$ other organization with similar remuneration

26. I have been motivated by my organization to do extra work $\begin{array}{lllllll}1 & 2 & 3 & 4 & 5\end{array}$ for my job that isn't normally expected for me

27. Time seems to drag while I am on the job $\quad \begin{array}{lllllll}1 & 2 & 3 & 4 & 5\end{array}$

28. Board of Internal Revenue explicitly disallow tax deductions $\begin{array}{llllllll}1 & 2 & 3 & 4 & 5\end{array}$ for bribes to public officials

29. Board of Internal Revenue raises awareness among taxpayers $\begin{array}{lllllll}1 & 2 & 3 & 4 & 5\end{array}$ that bribes are not deductible 
30. Board of Internal Revenue Staff are authorised to report

suspicious of corruption by taxpayers to the appropriate law enforcement authority

31. Board of Internal Revenue uses tax information sharing $\begin{array}{lllll}1 & 2 & 3 & 4 & 5\end{array}$ agreements with other States Board of Internal Revenue to obtain and provide information to determine whether a deducted payment constitutes a bribe.

THANK YOU FOR YOUR COOPERATION 